\title{
Snow observations in Mount Lebanon (2011-2016)
}

\author{
Abbas Fayad ${ }^{1,2}$, Simon Gascoin ${ }^{1}$, Ghaleb Faour ${ }^{2}$, Pascal Fanise $^{1}$, Laurent Drapeau $^{1}$, Janine Somma ${ }^{3}$, \\ Ali Fadel ${ }^{2}$, Ahmad Al Bitar ${ }^{1}$, and Richard Escadafal ${ }^{1}$ \\ ${ }^{1}$ Centre d'Etudes Spatiales de la Biosphère (CESBIO), UPS/CNRS/IRD/CNES, Toulouse, France \\ ${ }^{2}$ National Council for Scientific Research/Remote Sensing Center (CNRS/NCRS), Beirut, Lebanon \\ ${ }^{3}$ Remote Sensing Lab, Department of Geography, Saint Joseph University, Beirut, Lebanon
}

Correspondence to: Abbas Fayad (abbas.fayad@gmail.com)

Received: 16 January 2017 - Discussion started: 22 February 2017

Revised: 28 May 2017 - Accepted: 26 June 2017 - Published: 15 August 2017

\begin{abstract}
We present a unique meteorological and snow observational dataset in Mount Lebanon, a mountainous region with a Mediterranean climate, where snowmelt is an essential water resource. The study region covers the recharge area of three karstic river basins (total area of $1092 \mathrm{~km}^{2}$ and an elevation up to $3088 \mathrm{~m}$ ). The dataset consists of (1) continuous meteorological and snow height observations, (2) snowpack field measurements, and (3) medium-resolution satellite snow cover data. The continuous meteorological measurements at three automatic weather stations (MZA, $2296 \mathrm{~m}$; LAQ, $1840 \mathrm{~m}$; and CED, $2834 \mathrm{~m}$ a.s.l.) include surface air temperature and humidity, precipitation, wind speed and direction, incoming and reflected shortwave irradiance, and snow height, at 30 min intervals for the snow seasons (November-June) between 2011 and 2016 for MZA and between 2014 and 2016 for CED and LAQ. Precipitation data were filtered and corrected for Geonor undercatch. Observations of snow height (HS), snow water equivalent, and snow density were collected at 30 snow courses located at elevations between 1300 and $2900 \mathrm{~m}$ a.s.l. during the two snow seasons of 2014-2016 with an average revisit time of 11 days. Daily gap-free snow cover extent (SCA) and snow cover duration (SCD) maps derived from MODIS snow products are provided for the same period (2011-2016). We used the dataset to characterize mean snow height, snow water equivalent (SWE), and density for the first time in Mount Lebanon. Snow seasonal variability was characterized with high HS and SWE variance and a relatively high snow density mean equal to $467 \mathrm{~kg} \mathrm{~m}^{-3}$. We find that the relationship between snow depth and snow density is specific to the Mediterranean climate. The current model explained $34 \%$ of the variability in the entire dataset (all regions between 1300 and $2900 \mathrm{~m}$ a.s.l.) and $62 \%$ for high mountain regions (elevation 2200-2900 m a.s.l.). The dataset is suitable for the investigation of snow dynamics and for the forcing and validation of energy balance models. Therefore, this dataset bears the potential to greatly improve the quantification of snowmelt and mountain hydrometeorological processes in this data-scarce region of the eastern Mediterranean. The DOI for the data is https://doi.org/10.5281/zenodo.583733.
\end{abstract}

\section{Introduction}

Water scarcity is a growing concern in Lebanon due to the unsustainable water resource management, the limited accessibility to the water sources, increasing water demand by all sectors, increasing water pollution, and sea water intrusion (MOEW, 2010; UNDP, 2014; Kalaoun et al., 2016). Lebanon receives on average $830 \mathrm{~mm}$ of precipitation per water year (September-August) (MOEW, 2010). Most pre- cipitation falls during the winter season (December-March). The two Lebanese mountain chains, the Mount Lebanon and the Anti-Lebanon Mountains, receive between 50 and $67 \%$ of the total annual precipitation as snow (UNDP, 2014). This is mainly due to the orographic enhancement of the precipitation on the western slope of the mountain chains. The Mount Lebanon range has an average elevation above $2200 \mathrm{~m}$ and stretches over a distance of $150 \mathrm{~km}$ parallel to the Mediterranean coast, therefore causing enhanced orographic uplift 


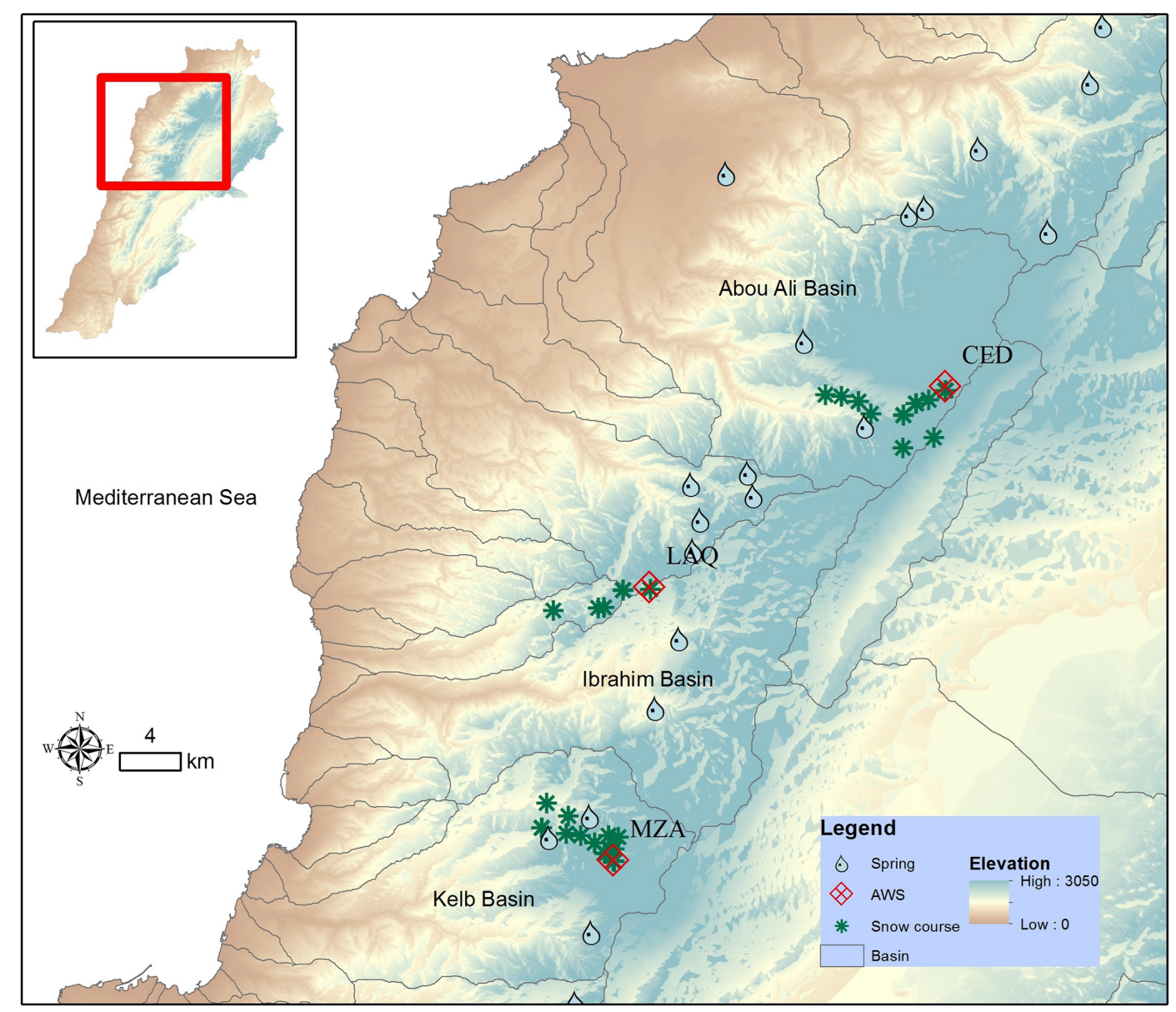

Figure 1. Location of the three study river basins in Mount Lebanon and the location of the three automatic weather stations (AWSs). Points indicates the location of the snow courses. Snow height (HS), snow density, and snow water equivalent (SWE) were measured at 30 snow courses for the two snow years (2014-2016): 9 snow courses at Cedars between 1800 and 2900 m a.s.1., 15 snow courses between Faraya and Mzar between 1350 and $2350 \mathrm{~m}$, and 6 snow courses between Ehmej and Laqlouq (elevation range between 1350 and $1850 \mathrm{~m}$ ).

of moist air masses. Due to the influence of the Mediterranean climate (wet winter, dry summer) most of the precipitation above $1200 \mathrm{~m}$ a.s.l. falls as snow on Mount Lebanon (Shaban et al., 2004; Aouad-Rizk et al., 2005; Mhawej et al., 2014; UNDP, 2014). The average contribution of snowmelt to spring and river discharge in Mount Lebanon was estimated at $30 \%$ by Telesca et al. (2014). Snowmelt contributes to the recharge of karstic aquifers and springs of all the watersheds located in the windward regions of Mount Lebanon (Fig. 1) (e.g., Bakalowicz et al., 2008; Doummar et al., 2014). This snow contribution to groundwater recharge can reach up to $75 \%$ in the upper mountainous aquifers, where the groundwater recharge was estimated at $81 \%$ from precipitation in the snow-dominated regions of the El Kelb Basin (Margane et al., 2013; Königer and Margane, 2014). The snowmelt contribution from high-elevation regions (above $1800 \mathrm{~m}$ a.s.l.) was estimated to contribute to around $56 \%$ of the major spring discharge at the lowland regions (Margane et al., 2013). The coastal watersheds, such as the EL Kelb
Basin, are the major sources of water for the coastal population, where most of the Lebanese population is located.

Although snow is recognized as a major component of the hydrologic system in Mount Lebanon (Shaban et al., 2004; Aouad-Rizk et al., 2005; Bakalowicz et al., 2008; Mhawej et al., 2014; Königer and Margane, 2014), the link between snowmelt and the hydrological processes remains poorly characterized on the basin scale. This can be attributed to the (1) lack of an operational snow observation network in Lebanon and (2) limited number of published basin-scale hydrometeorological datasets. Meteorological stations operated by the department of civil aviation are usually located below the snowline (maximum elevation at $1220 \mathrm{~m}$ a.s.l.) and the few stations located in the mountainous regions (elevation range $1510-1890 \mathrm{~m}$ a.s.l.) are not equipped to measure snowfall. Furthermore, only a few datasets on precipitation, temperature, snow, groundwater recharge and streamflow are available for basin-scale studies (e.g., Königer and Margane, 2014). Existing datasets, available through published mate- 
rial, are usually limited to (1) national-scale studies with monthly or yearly means (Shaban et al., 2004; Corbane et al., 2005; Mhawej et al., 2014; Telesca et al., 2014), (2) multiyear daily spring discharge and precipitation time series (e.g., Hreiche et al., 2007), (3) seasonal observations collected for mesoscale catchment studies (Bernier et al., 2003; AouadRizk et al., 2005; Doummar et al., 2014), and (4) local-scale snowpack observations (e.g., Somma et al., 2006, 2014). In most cases the research datasets are not made publicly available.

In this paper, we present a dataset targeted at the study of the mountain and snow hydrology in three mesoscale basins (area $256-513 \mathrm{~km}^{2}$ ) located on the west slope of Mount Lebanon (Fig. 1). The dataset consists of (1) continuous meteorological and snow height observations collected at three automatic weather stations (AWSs) (2011-2016), (2) snowpack field measurements collected during two snow seasons (2014-2016), and (3) medium-resolution satellite observations of the snow cover extent at a daily time step (MODIS). We use these data to characterize the variability in key snowpack properties. The dataset presented in this paper is unique because it is the only dataset that includes a range of continuous snow and meteorological measurements in the mountain region of Lebanon at the elevation regions between 1300 and $2900 \mathrm{~m}$ a.s.l. The data presented are readily suitable for the forcing and validation of a snowpack energy and mass balance model. The data also can be useful for further hydrometeorological studies such as climate model downscaling or hydrological modeling for water resource management.

The study area is described in Sect. 2. Meteorological observations and post processing methods, snow course measurement protocols, and MODIS data processing are presented in Sect. 3. Section 4 provides a summary of the observations and an example application on using the datasets to derive the relationships between HS, snow water equivalent (SWE), and snow density. Data accessibility and conclusions are presented in Sects. 5 and 6, respectively.

\section{Study area}

This study's measurements were collected in the upper area of three mesoscale snow-dominated mountain basins located in Mount Lebanon with an average centroid located at $34.10^{\circ} \mathrm{N}$ and $35.90^{\circ} \mathrm{E}$ and covering a total area of $1092 \mathrm{~km}^{2}$ (Fig. 1). These basins belong to the "coastal watersheds", which supply fresh water to major Lebanese cities, including Beirut. Due to the influence of the Mediterranean climate, most precipitation falls between November and April. Winter precipitation (December-March) accounts for $84 \%$ of the total annual precipitation. Most precipitation above $1600 \mathrm{~m}$ a.s.l. falls as snow. The topography of the midelevation regions (1600-2200 m a.s.l.) is usually rugged terrain (Fig. 2). The mid-elevation and high-elevation plateau are found at elevation ranges between 2300 and $2500 \mathrm{~m}$ and between 2700 and 3000, respectively (Fig. 2). The treeline is located at $1550 \mathrm{~m}$ a.s.l., where sparse scrublands dominate most of the land cover. The retreat of the natural tree line is due to the increased deforestation and urbanization. The natural tree line which can be still found in sparse, small, forested regions extends up to $2450 \mathrm{~m}$ in Abou Ali and $1900 \mathrm{~m}$ in the Ibrahim and El Kelb basins. Most snowfed karstic springs are located at altitudes between 300 and $2280 \mathrm{~m}$ a.s.l. The physical attributes of the three study basins are shown in Table 1.

\section{Data description and methods}

\subsection{Meteorological data}

The three AWSs were installed in Mount Lebanon above the winter snowline (approximately $1550 \mathrm{~m}$ a.s.l.) with the primary objective to monitor the meteorological variables that drive seasonal snowpack evolution on Mount Lebanon (Figs. 1 and 2). The Laqlouq AWS (LAQ) is located in a monastery at $1840 \mathrm{~m}$ a.s.l., the Mzar station (MZA) is located in a ski resort domain at $2296 \mathrm{~m}$ a.s.l., and the Cedars AWS (CED) (2834 m a.s.l.) is located on the higher plateau below the mountain's peak at Qornet El Sawda, $3088 \mathrm{~m}$ a.s.l. (Fig. 1, Table 2). The LAQ station is in a relatively flat plain area with fruit trees, bare rocks, and sparse, short grasslands. The MZA station is located on one of the mediumelevation peaks in a mountainous region with rugged terrain (maximum elevation in the area is $\sim 2600 \mathrm{~m}$ a.s.l.) with dominant bare soils and sparse speargrass grassland. The CED AWS is located on a higher plateau with dominant bare rocks and sparse shrubs and grasslands at lower elevations (1600-2200 m a.s.l.). Wind effects on snow cover are more noticeable in MZA due to the combined effect of topography and higher wind velocities. The three stations are operated under a joint program for establishing a network for snow observation (NSO). The program, established in 2010, is a collaboration between the Institut de Recherche pour le Développement (IRD, France), the Centre d'Etudes Spatiales de la Biosphere (CESBIO, France), the National Council for Scientific Research - Remote Sensing Center (CNRS/NCRS, Lebanon), and the University of Saint Joseph (USJ, Lebanon).

Meteorological data are available starting from snow season (December-June) 2011 for Mzar AWS and the monitoring network became fully operational in snow season 20142015 with the installation of the third AWS (LAQ) at Laqlouq (Table 2). Meteorological data - including snow height, temperature, relative humidity, incoming and reflected shortwave solar radiation, wind speed and direction, and atmospheric pressure - are collected at the three sites using sensors mounted on towers (Fig. 3). Longwave radiation, which is an important component of the energy balance in Mediterranean regions (Herrero and Polo, 2016), is not measured. However, incoming longwave radiation can be estimated from 


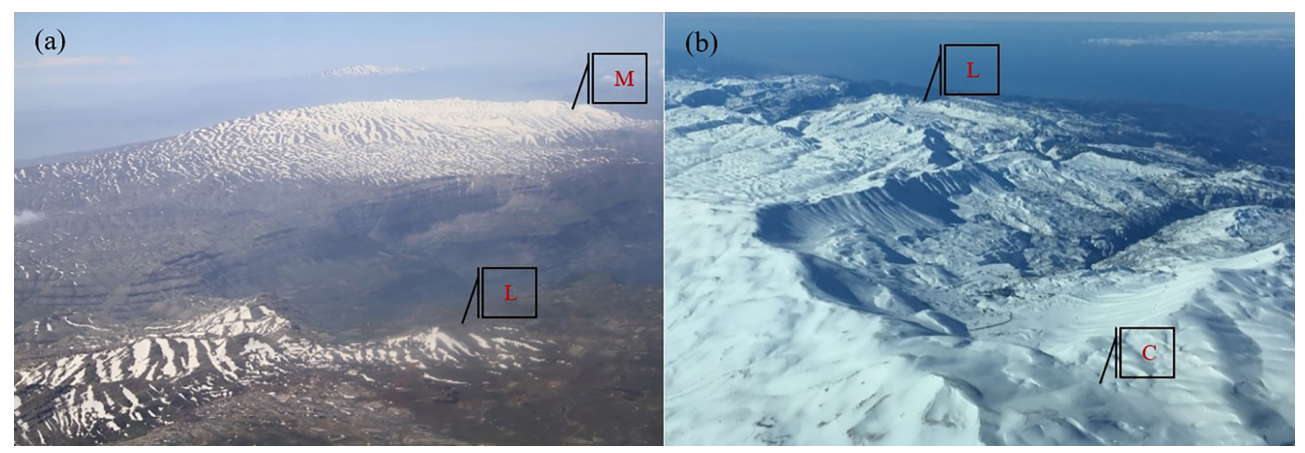

Figure 2. Overview of the mountain topography at (a) Laqlouq and Mzar and (b) Cedars, Mount Lebanon. The images were captured on 6 May 2011 (a) and 21 February 2015 (b) (courtesy of the author). The locations of the AWSs are shown approximately on the images where the letters M, L, and C represent the stations at MZA, LAQ, and CED, respectively (see Table 1). The topography near Laqlouq (LAQ) is a relatively low plain (elevation between 1600 and $1800 \mathrm{~m}$ a.s.l.) and low-elevation mountains (1900-2100 m a.s.1.). The region near Mzar (MZA) is characterized by rugged terrain (1600-2200 m a.s.1.) and mid-elevation plateau (elevation range 2300-2500 m). The high-elevation plateau (shown partially in panel b near Cedars, CED) have an elevation range between 2700 and 3000 ma.s.l. Snow persists until the end of May in the mid-elevation mountain regions (plateau and rugged terrain region above $2300 \mathrm{~m}$ a.s.1.). The low-elevation and mid-elevation regions (1300-2000 m a.s.1.) are usually snow-free by mid-March to mid-April.

Table 1. Attributes of the three snow-dominated basins in Mount Lebanon described in this study.

\begin{tabular}{|c|c|c|c|c|c|}
\hline $\operatorname{Basin}^{\mathrm{a}}$ & $\begin{array}{r}\text { Area } \\
\left(\mathrm{km}^{2}\right)\end{array}$ & $\begin{array}{r}\text { elevation range } \\
\text { (average) }^{\mathrm{b}} \\
\text { m a.s.l. }\end{array}$ & $\begin{array}{l}\text { Dominant land } \\
\operatorname{cover}^{\mathrm{c}}(\%)\end{array}$ & $\begin{array}{r}\text { AWS Elevation, } \\
\text { m a.s.l. (year } \\
\text { installed) }\end{array}$ & $\begin{array}{l}\text { Snow course count } \\
(\text { elevation range })^{\mathrm{e}}\end{array}$ \\
\hline 1 & 513 & $0-3088$ (1202) & Clear grassland $(20 \%)$ & 2834 (2013) & $9(1650-2900)$ \\
\hline 2 & 323 & $0-2681(1547)$ & Clear grassland $(30 \%)$ & $1840(2014)$ & $6(1300-1850)$ \\
\hline 3 & 256 & $0-2619(1381)$ & Clear grassland $(16 \%)$ & $2296(2011)$ & $15(1300-2300)$ \\
\hline
\end{tabular}

${ }^{a}$ Basins are Abou Ali (1), Ibrahim (2), and El Kelb (3) (Fig. 1). ${ }^{b}$ Values are derived for the national $10 \mathrm{~m}$ DEM (NCRS). ${ }^{\mathrm{c}}$ Source: land-use land cover map of Lebanon (NCRS, 2015). ${ }^{\mathrm{d}}$ Source: Institut de recherche pour le développement (IRD) (Table 2). ${ }^{\mathrm{e}}$ Snow course observations were conducted between December and May over two snow years (2014-2016) (Fig. 1).

air temperature and humidity measurements at the stations (Brutsaert, 2013). Incoming solar radiation can also be used to better constrain the cloud fraction in the computation of the longwave radiation. Each station consists of a data logger (CR1000; Campbell Scientific Inc., Utah, USA) and a precipitation gauge (T-200B; Geonor Inc., Eiksmarka, Norway), a snow depth sensor (SR50A; Campbell Scientific Inc., Utah, USA), an air temperature and humidity sensor (CS215; Campbell Scientific Inc., Utah, USA), an incoming and reflected shortwave solar radiation sensor (SP LITE 2 pyranometer; Kipp \& Zonen, Netherlands), and a wind speed and direction sensor (Alpine v05103-45L, Young, USA). Data are transmitted via a GPRS modem every $8 \mathrm{~h}$. Observations from the three AWSs are collected at $30 \mathrm{~s}$ and then aggregated into $30 \mathrm{~min}$ averages. Temperature and humidity sensor are installed at $2.4 \mathrm{~m}$ in MZA, $3.9 \mathrm{~m}$ in LAQ, and $4.2 \mathrm{~m}$ in CED. Wind speed sensors are installed at $2.6 \mathrm{~m}$ in MZA, $4.2 \mathrm{~m}$ in LAQ, and $4.9 \mathrm{~m}$ in CED. Snow height observations were recorded automatically at each station using an acoustic snow gauge installed at $2.0 \mathrm{~m}$ in MZA and at $4.0 \mathrm{~m}$ in CED and LAQ. Precipitation data are recorded at a snow gauge placed in the proximity of the station (Fig. 3). Precip- itation has been observed since 2012 at MZA (2012-2016) and since 2014 at LAQ (2014-2016). The CED station was equipped with a Geonor in December 2016. Data for precipitation were missing during the first year (2011-2012) at MZA and shortwave solar radiation measurements began in snow season 2014. CED AWS data between 24 April and 30 June 2015 were removed due to station rotation. The wind speed data located at CED were discarded after 15 January 2016 due to sensor malfunction. Missing data were less than $10 \%$ for all stations after the network became fully operational (2014-2016).

Raw data collected at the stations underwent basic quality control, including checks for missing data and boundary values. We performed further quality control for the $30 \mathrm{~min}$ and daily average observations by screening outliers and erroneous data following rules given by Serreze et al. (1999), Shafer et al. (2000), and Estévez et al. (2011). Humidity, pyranometers, and wind sensors were unheated and thus may be subject to error when covered by frost (Malek, 2008). The temperature sensors are protected against solar radiation (Huwald et al., 2009) using radiation shield and are naturally ventilated. The accumulation of frost on the sensor 
Table 2. Meteorological stations.

\begin{tabular}{llrrl}
\hline Station $^{\mathrm{a}}$ & Location & $\begin{array}{r}\text { Elevation, } \\
\text { ma.s.l. }\end{array}$ & $\begin{array}{r}\text { Record period } \\
(30 \text { min averages })^{\mathrm{b}}\end{array}$ & $\begin{array}{l}\text { Coordinates } \\
\text { (WGS84) }^{(\text {W }}\end{array}$ \\
\hline CED & Cedars & 2834 & $2013-2016$ & $34.27^{\circ} \mathrm{N}, 36.09^{\circ} \mathrm{E}$ \\
LAQ & Laqlouq & 1840 & $2014-2016$ & $34.14^{\circ} \mathrm{N}, 35.88^{\circ} \mathrm{E}$ \\
MZA & Mzar & 2296 & $2011-2016$ & $33.98^{\circ} \mathrm{N}, 35.86^{\circ} \mathrm{E}$ \\
\hline
\end{tabular}

a See Table 3 for sensor description. ${ }^{\mathrm{b}}$ The time period cover the snow season between 1 November and 30 June.

Table 3. Sensor specifications and quality control checks for semi-hourly and daily data - adopted after Estévez et al. (2011) and WMO (2008).

\begin{tabular}{|c|c|c|c|c|c|}
\hline Sensor & Variable & $\begin{array}{l}\text { Accuracy } \\
\text { (sensitivity) }\end{array}$ & Range test & Step test & Cross-validation test \\
\hline $\begin{array}{l}\mathrm{T}-200 \mathrm{~B}(1000 \mathrm{~mm} \text { at } \\
\text { MZA and LAQ) and } \\
\left.1500 \mathrm{~mm}^{2} \text { at } C E D^{*}\right)\end{array}$ & $\begin{array}{l}\text { Precipitation } \\
(\mathrm{mm})\end{array}$ & $\begin{array}{l}0.1 \% \text { full scale } \\
(0.075-0.1)\end{array}$ & $\begin{array}{l}0 \leq P_{\mathrm{sh}} \leq 120 \\
0 \leq P \leq 508\end{array}$ & $\begin{array}{l}0 \leq P_{\mathrm{sh}} \\
P(0-6 \mathrm{~h}) \leq P(0-24 \mathrm{~h})\end{array}$ & $\mathrm{RH}_{\mathrm{sh}}>80 \%$ \\
\hline SR50 & $\begin{array}{l}\text { Snow height } \\
(\mathrm{cm})\end{array}$ & $\begin{array}{l} \pm 1 \\
(0.25)\end{array}$ & $0 \leq \mathrm{HS}_{\mathrm{sh}} \leq 450$ & & $\begin{array}{l}\text { Maximum HS }(0-24 \mathrm{~h}) \\
<0.15 \times P(0-24 \mathrm{~h})\end{array}$ \\
\hline $\mathrm{CS} 215$ & $\begin{array}{l}\text { Temperature } \\
\left({ }^{\circ} \mathrm{C}\right)\end{array}$ & \pm 0.4 & $-30<T<50$ & $\left|T_{\mathrm{sh}}-T_{\mathrm{sh}_{-1}}\right|<3$ & $T_{\mathrm{sh}} \neq T_{\mathrm{sh}_{-1}} \neq T_{\mathrm{sh}_{-2}} \neq T_{\mathrm{sh}_{-4}}$ \\
\hline SP LITE 2 & $\begin{array}{l}\text { Incoming } \\
\text { Radiation } \\
\text { Reflected } \\
\text { Radiation }\end{array}$ & & $\begin{array}{l}-1<\mathrm{SwI}_{\mathrm{sh}}<1500 \\
-1<\mathrm{SwR}_{\mathrm{sh}}<1500\end{array}$ & $\begin{array}{l}0 \leq\left|\mathrm{SwI}_{\mathrm{sh}}-\mathrm{SwR}_{\mathrm{sh}_{-1}}\right| \leq 555 \\
0 \leq \mathrm{SwR}_{\mathrm{sh}}-\mathrm{SwR}_{\mathrm{sh}_{-1}} \leq 550\end{array}$ & $\begin{array}{l}\text { For } \mathrm{SwI}_{\mathrm{sh}}>0 \& \mathrm{SwR} \mathrm{R}_{\mathrm{sh}}>0 \\
{[0<\operatorname{albedo}(\mathrm{SwR} / \mathrm{SwI})<0.95]}\end{array}$ \\
\hline $\mathrm{CS} 215$ & $\begin{array}{l}\text { Relative } \\
\text { Humidity }(\%)\end{array}$ & \pm 0.2 & $0.8<\mathrm{RH}<103$ & $\left|\mathrm{RH}_{\mathrm{sh}}-\mathrm{RH}_{\mathrm{sh}_{-1}}\right| \leq 45$ & \\
\hline Young 05103 - alpine & $\begin{array}{l}\text { Wind direction } \\
(\operatorname{deg})\end{array}$ & \pm 0.3 & $0 \leq \mathrm{Wd} \leq 360$ & & $\begin{array}{l}\mathrm{Ws}_{\mathrm{sh}}=0 \& \mathrm{Wd}_{\mathrm{sh}}=0 \\
\mathrm{Ws}_{\mathrm{sh}} \neq \mathrm{Ws}_{\mathrm{sh}_{-1}} \\
\mathrm{Ws}_{\mathrm{sh}} \neq \mathrm{Ws}_{\mathrm{sh}_{-2}} \neq \mathrm{Ws}_{\mathrm{sh}_{-4}} \\
\mathrm{Wd}_{\mathrm{sh}} \neq \mathrm{Wd}_{\mathrm{sh}_{-1}} \neq \mathrm{Wd}_{\mathrm{sh}_{-4}} \\
\mathrm{Wd}_{\mathrm{sh}} \neq \mathrm{Wd}_{\mathrm{sh}_{-2}}\end{array}$ \\
\hline
\end{tabular}

$P$ and $P_{\mathrm{sh}}$ : daily and semi-hourly precipitation; HS and $\mathrm{HS}_{\mathrm{sh}}$ : daily and semi-hourly snow height; $T:$ mean air temperature, respectively; $T_{\mathrm{sh}}:$ semi-hourly air temperature; SwI and SwR: incoming and reflected solar radiation, respectively (sh denotes semi-hourly); $\mathrm{RH}_{\text {and }} \mathrm{RH}_{\mathrm{sh}}$ : daily mean and semi-hourly relative humidity; and Ws and Wd: mean wind speed and mean wind direction, respectively (sh denotes semi-hourly). For HS we used visual interpretation to account for snow height following snowfall, or when SR50 measurements are lost, assuming the difference in HS over a single day is less than total daily precipitation multiplied by an average fresh snow density of $0.15 \mathrm{~g} \mathrm{~cm}^{-1}$. The sensor's field life cycle is $\sim 3$ years. * The snow gauge (model T-200B, $1500 \mathrm{~mm}$ ) was installed in October 2016 and measurements will be available starting from snow year 2016-2017.

was observed during multiple field visits at MZA and CED. These events usually coincide with the week following storm events.

For precipitation $(P)$, air temperature $(T)$, snow height (HS), and humidity (RH), we used running step tests to detect abrupt jumps in means, especially during storm events (Table 3). Incoming and reflected shortwave solar (SR) radiation measurements were screened using snow half-hourly albedo, by eliminating data that do not give a positive albedo $(0 \leq$ albedo $\leq 1)$. We used a positive snow height (HS) to detect the presence or absence of snow. Data ranges were used for $P\left(0-240 \mathrm{~mm} \mathrm{~h}^{-1}\right), T\left(-30\right.$ to $\left.+40^{\circ} \mathrm{C}\right), \mathrm{RH}(0-100 \%)$, HS $(0-4.5 \mathrm{~m})$, and SR $\left(0-1500 \mathrm{~W} \mathrm{~m}^{-2}\right)$. For the two snow seasons 2015-2016 (November-June) data record retained at the three stations were $71.1,95.4$, and $94.3 \%$ of the total datasets for CED, LAQ, and MZA, respectively. An example of the semi-hourly precipitation and temperature observations at Laqlouq for the snow seasons (2014-2016) is shown in Fig. 4.

\subsection{Correcting for Geonor undercatch}

The output data from the Geonor accumulating gauge were post-processed in order to identify and correct biased observations, to determine the precipitation type, and to correct the Geonor precipitation undercatch. Three types of biases were found in the Geonor observations, similarly to previous studies (Harder and Pomeroy, 2013; and Pan et al., 2016): (1) erroneous readings associated with the Geonor 


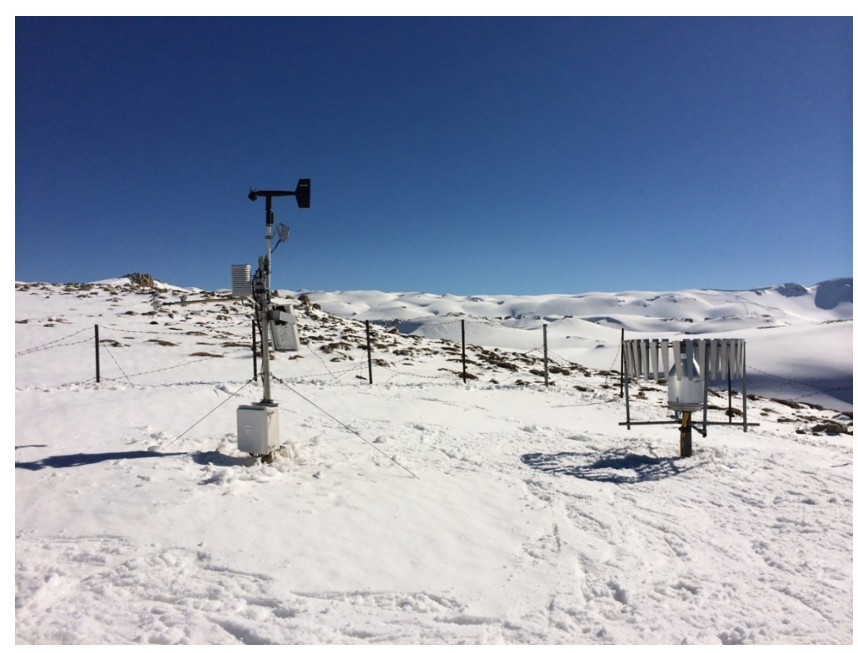

Figure 3. Automatic weather station at Mzar (MZA) (2296 m a.s.1.) where all sensors are located on the tower and the precipitation gauge is located to the right of the station. Image captured on 5 March 2015 (courtesy of the author).

field servicing (i.e., emptying and/or adding of antifreeze and oil to the Geonor bucket); (2) jitters and diurnal noise due to wind speed (e.g., MZA) and changes in temperature are similar to those found in sites with strong diurnal changes in temperature, radiation, and wind speed (e.g., Harder and Pomeroy 2013; Pan et al., 2016); and (3) long-term drift results from evaporation within the bucket, which occurs at the end of snow season, when air temperature is high. We post-processed the raw precipitation data using a supervised correction similar to the one described in Harder and Pomeroy (2013) by performing the following steps. (1) The Geonor raw data were adjusted to account for when the gauge is emptied and/or filled with oil and antifreeze. (2) We used the predefined values for range test and cross validation tests (Table 3) to automatically flag and remove erroneous peaks (e.g., $P_{\mathrm{sh}}>120 \mathrm{~mm}$ ). (3) All erroneous changes in the calculated raw cumulated precipitation (raw $P_{\mathrm{sh}}<-20 \mathrm{~mm}$ and $>20 \mathrm{~mm}$ ) were removed. (4) We flagged and removed all cumulated precipitation greater than $1000 \mathrm{~mm}$ (equal to the maximum capacity of the Geonor bucket), and the precipitation data for the same time period was set to "no data" in the final dataset. (5) All missing cumulative precipitation observations were assumed to be equal to the previous observed observation for running the filter. (6) We used a supervised rolling maximum filter (Harder and Pomeroy, 2013) to remove the biased precipitation observation. The filter was run sequentially on the time series of the cumulated precipitation: the precipitation observation was retained if it was greater than the previous maximum.

The rolling maximum filter preserves the cumulative change in precipitation and the timing of precipitation events (Harder and Pomeroy, 2013) (Fig. 5). However, a visual check is needed to flag potential errors. We visually com- pared the auto-filtered data versus the raw data to (1) check for erroneous departures between the auto-filtered and raw data; (2) check whether the filter captured the start of a precipitation event and whether the calculated $P_{\text {sh }}$ occurred when humidity was greater than $80 \%\left(P_{\mathrm{sh}}\right.$ with low humidity values were removed); and (3) check and correct errors attributed to gauge drift events, which are associated with evaporation effects, that are not captured by the filter (Fig. 5a). We corrected these errors by manually replacing the filtered cumulated precipitation data to fit the actual change from the raw precipitation data (Fig. 5a). We made sure that the total sum of the replaced precipitation was equal to the cumulative observed precipitation which was assumed to be correct over the same time period. We also checked that the precise start and timing of precipitation events was preserved and that the long-term drift due to evaporation was eliminated (Fig. 5a).

The collection efficiency of precipitation gauges is influenced by the wind speed and a bias adjustment for solid precipitation is needed under windy conditions (Rasmussen et al., 2012; Buisán et al., 2017; Smith et al., 2017; Pan et al., 2016). Measurement errors due to gauge undercatch frequently range between 20 and $50 \%$ (Rasmussen et al., 2012). The catch efficiency for the Geonor with a single Alter shield decreases linearly to approximately $60 \%$ at wind speed $5 \mathrm{~m} \mathrm{~s}^{-1}$ (Thériault et al., 2012). The bias adjustment for precipitation undercatch is achieved by estimating the catch efficiency (CE) (wind speed relationship) of the precipitation gauge. The determination of CE requires the determination of precipitation type and that the wind speed is measured at gauge height (Rasmussen et al., 2012). The need for precipitation type separation is important because the influence of wind is much more pronounced for solid precipitation than for liquid precipitation (Rasmussen et al., 2012). In this study, we applied bias correction for the filtered precipitation data $\left(P_{\text {adj }}\right)$. For solid precipitation, we used the empirical relationship between catch efficiency and wind speed derived by Thériault et al. (2012) after Yang et al. (1998) and Rasmussen et al. (2001):

$$
\begin{aligned}
& P_{\text {cor }}=\frac{P_{\text {adj }}}{\mathrm{CE}}, \\
& \mathrm{CE}=\frac{100+\mathrm{Ws} \times C}{100},
\end{aligned}
$$

where $P_{\text {cor }}(\mathrm{mm})$ is the corrected precipitation, $P_{\text {adj }}(\mathrm{mm})$ is the measured precipitation after filtering, $\mathrm{CE}$ is the catch efficiency of the Geonor, Ws $\left(\mathrm{m} \mathrm{s}^{-1}\right)$ is the hourly mean wind speed at the gauge height, and $C$ is a constant and represents the gauge configuration parameter and is equal to -7.1 for the single Alter shield Geonor (Thériault et al., 2012). Over-correction is possible for snowfall events and occurs under the impact of blowing snow at high wind speeds (Pan et al., 2016). To limit overcorrection, we used a threshold for maximum wind speed. Thus, the CE was set to 0.44 (CE for $8 \mathrm{~m} \mathrm{~s}^{-1}$ ). We used this threshold since the median collection efficiency of the Geonor in the single Alter shield seemed 

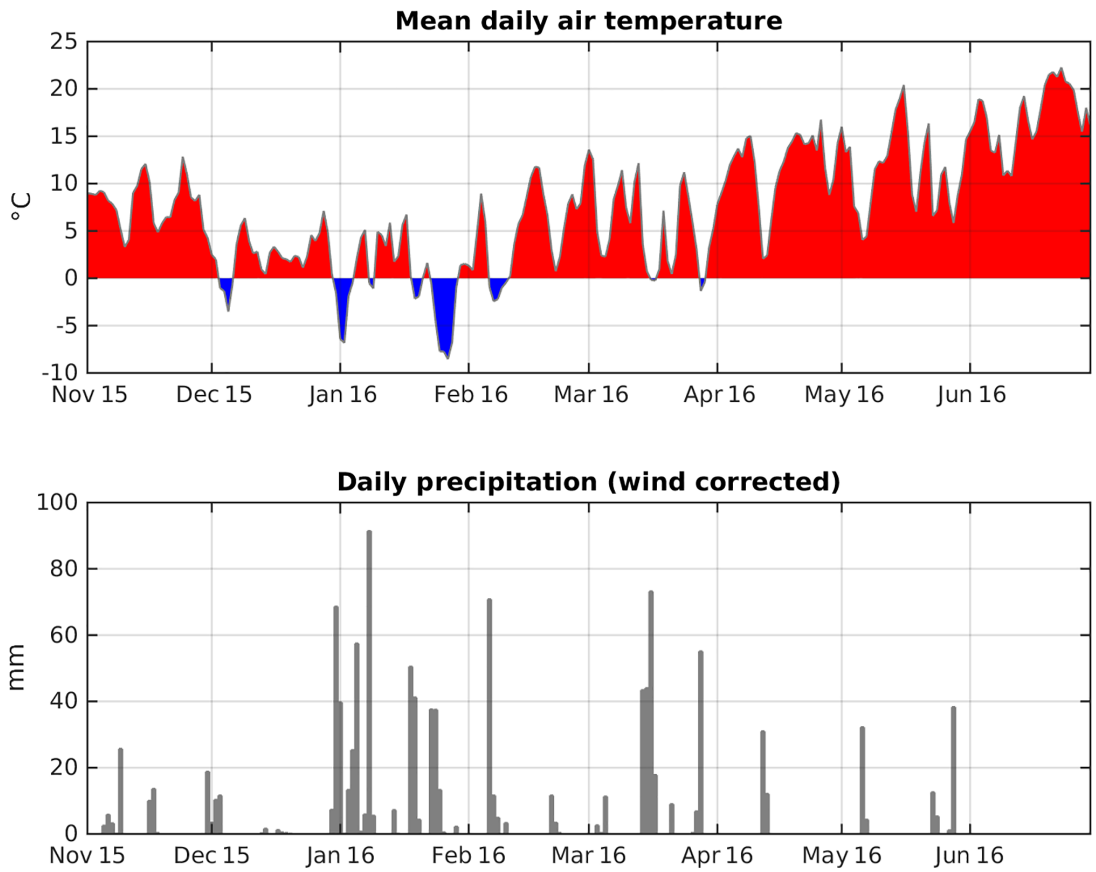

Figure 4. Example of daily precipitation and temperature observations at Laqlouq (1840 ma.s.1.) during snow season 2015-2016 (November-June).
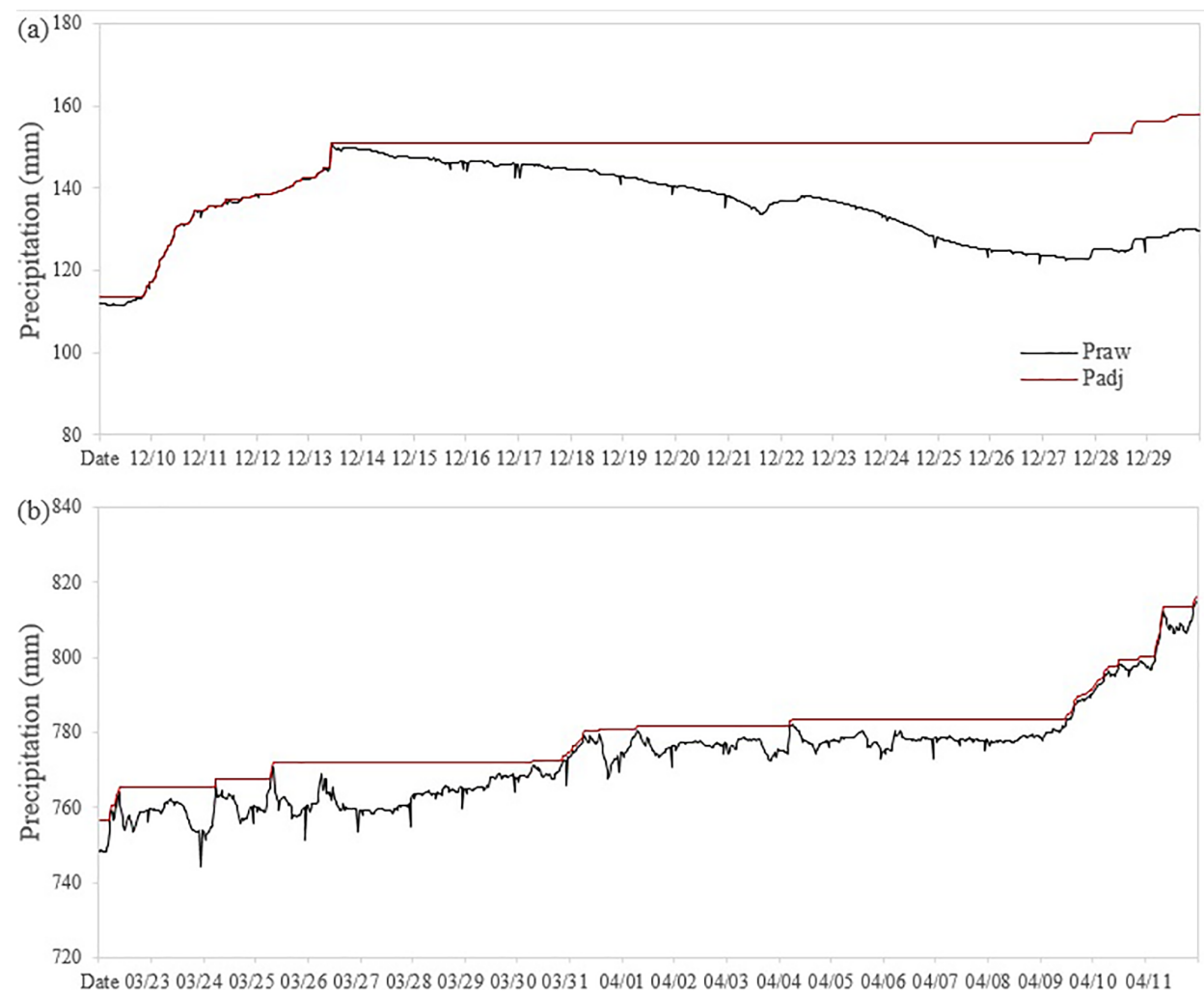

Figure 5. Examples of the jitters and diurnal noise filtering for Geonor T-200B weighing gauge (Praw: raw data; Padj: filtered data). (a) Significant evaporation occurred during winter season 2014 (e.g., MZA: 12-29 December 2013) and required manual correction (2829 December). No correction for the accumulation of raw precipitation between 22 and 23 December was made because the observed average humidity was below $15 \%$. (b) Filtering of jitters and diurnal noise (no manual correction) (e.g., MZA: 23 March-11 April 2015). 
to saturate at wind speeds greater than $8 \mathrm{~m} \mathrm{~s}^{-1}$ for a test site in Colorado (Thériault et al., 2012). The median wind speed recorded during precipitation events over the winter seasons of 2014-2016 ranged between 3.3 and $3.7 \mathrm{~m} \mathrm{~s}^{-1}$ for LAQ and 8.8 and $9 \mathrm{~m} \mathrm{~s}^{-1}$ for MZA with maximum recorded wind speed at 10 and $20.1 \mathrm{~m} \mathrm{~s}^{-1}$ for LAQ and MZA, respectively. We adjusted all rainfall measurements using the constant average catch efficiency for the single Alter shield Geonor estimated at $95 \%(\mathrm{CE}=0.953)$ (Devine and Mekis, 2008).

Wind speed at gauge height is required for the estimation of CE. We used the logarithmic wind profile to estimate the wind speed at the height of the Geonor gauge (Yang et al., 1998):

$\mathrm{Ws}(h)=\mathrm{Ws}(H)\left[\frac{\ln \left(\frac{h}{z_{0}}\right)}{\ln \left(\frac{H}{z_{0}}\right)}\right]$,

where $\mathrm{Ws}(h)$ is the estimated hourly wind speed $\left(\mathrm{ms}^{-1}\right)$ at the gauge height, $\mathrm{Ws}(H)$ is the measured mean hourly wind speed at the anemometer height, $h$ and $H$ are the heights (m) of the Geonor gauge and the anemometer, respectively, and $z_{0}$ is the roughness parameter $(\mathrm{m})$, set to $0.01 \mathrm{~m}$ for the winter snow surface and $0.03 \mathrm{~m}$ for short grass in the warm period (Yang et al., 1998). For this study, we set $z_{0}=0.01$ for the time period between December and March and $z_{0}=0.03$ for the rest.

Different approaches for precipitation phase determination have been summarized in Harpold et al. (2017). Most common methods rely on the use of mean air temperature $\left(T_{\mathrm{a}}\right)$ thresholds (e.g., Marks et al., 2013). In this study, we use a static threshold of $0{ }^{\circ} \mathrm{C}$ (Marks et al., 2013) to distinguish between snowfall and rainfall. All precipitation below or above the threshold are partitioned as snow or rain, respectively. This method was found to yield reliable snow precipitation in Idaho when cloud levels are at or close to the surface during storms and the $\mathrm{RH}$ is at or close to saturation (Marks et al., 2013). The Mount Lebanon meteorological conditions during storm events are similar and are usually characterized by RH saturation and cloud levels are near the surface.

\subsection{Snow course data}

We identified 30 different snow courses with lengths varying between 75 and $400 \mathrm{~m}$, within the upper area of the three basins (Fig. 1). The locations of the snow courses were selected based on accessibility, representativeness of the snow cover within the region (suggesting, whenever possible, one snow course for relatively flat and low slope regions and two snow courses representing the maximum and minimum snow depth transects in rough topographic regions). Snow courses were spaced at $\sim 100 \mathrm{~m}$ vertical elevation. All snow courses had a slope of less than $30 \%$. Field measurements of snow depth, snow density, and SWE were carried out over two snow seasons (2014-2016) with an average revisit time of 11.4 days for each snow course. A total of 649 snow course measurements are reported and can be found at https://doi.org/10.5281/zenodo.583733. Snow depth was measured manually, to the nearest $1 \mathrm{~cm}$, using a $3 \mathrm{~m}$ snow probe, at $5 \mathrm{~m}$ intervals along each snow course. Snow density was measured using a federal snow sampler (snow cutter inner diameter at $3.772 \mathrm{~cm}$ ) along each snow course at $25 \mathrm{~m}$ intervals for snow courses shorter than $100 \mathrm{~m}$ and at $50 \mathrm{~m}$ intervals for longer snow courses, so at least 3-5 snow density measurements were recorded at each snow course site. Snow density and SWE protocol consisted of weighing the empty tube. The snow tube was then plunged into the snowpack and the snow depth marker on the tube was recorded. Once the core was removed the snow depth of the snowpack was checked to make sure that at least $80 \%$ of the snowpack has been cored (Dixon and Boon, 2012). We also measured the snowpack HS using a marked snow probe $(1 \mathrm{~cm})$ to make sure no snow was left unsampled. Any amount of soil entering the snow cutter, especially during the melt season, was removed and reported alongside the HS measurements. The combined weight of the tube and core was recorded. Each snow sample was weighed three times (five times under windy conditions) and the average snow weight was registered. Under windy conditions maximum and minimum weights were removed and the weight was averaged for the three measurements. The mass of the snow core sample was calculated by subtracting the empty tube mass from the combined tube and snow core mass. Snow courses with an HS of less than $30 \mathrm{~cm}$ and where the snow cover was less than $50 \%$ (based on visual interpretation) were sampled by taking bulk density measurements. Bulk density measurement consisted on taking four snow core samples at a single location and weighing the total mass for the combined four samples, the average density is then reported for this point-location. Weighing scales were validated under normal weather conditions by taking 50 measures of the empty snow tube and thus suggesting an accuracy of $98.75 \%$ when using a $2 \mathrm{~m}$ snow tube. Snow density and snow water equivalent were calculated using (Eqs. 4 and 5):

$\rho_{\mathrm{s}}=\frac{m_{\mathrm{sample}}}{\pi r^{2} \times \mathrm{HS}}$,

$\mathrm{SWE}=\mathrm{HS} \frac{\rho_{\mathrm{S}}}{\rho_{\mathrm{W}}}$,

where $\rho_{\mathrm{s}}$ is the density of the snow core sample $\left(\mathrm{g} \mathrm{cm}^{-3}\right)$, $\rho_{\mathrm{W}}$ is the density of water $\left(1 \mathrm{~g} \mathrm{~cm}^{-3}\right), m_{\text {sample }}$ is the mass of the snow core sample, $r$ is the inside radius of the snow tube cutter $(3.772 \mathrm{~cm})$, and HS is snow height $(\mathrm{cm})$.

\subsection{Snow cover extent and snow cover data}

Daily maps of the snow cover extent at $500 \mathrm{~m}$ spatial resolution were generated for the three watersheds from the MODIS snow products. We used the "binary" snow cover area sub-dataset from MOD10A1 (Terra) and MYD10A1 (Aqua) collection 5 products from the National Snow and 
Ice Data Center (Hall et al., 2006). Mount Lebanon falls between MODIS grid tiles h20v05 and h21v05. All available tiles from 1 September 2011 to 31 August 2016 were assembled and resampled to $500 \mathrm{~m}$ with a nearest-neighbor method in UTM $36 \mathrm{~N}$ using the MODIS reprojection tool over a rectangular spatial subset (upper left $x=730 \mathrm{~km}$, $y=3830 \mathrm{~km}$; lower right $x=850 \mathrm{~km}, y=3680 \mathrm{~km}$ ). Then we ran a gap-filling code which is fully described in Gascoin et al. (2015) to interpolate the missing information mostly caused by cloud cover. The algorithm utilizes the topographic information (elevation and aspect) from the ASTER global digital elevation map, which was resampled to the same resolution. The output is a series of daily, gap-free raster maps of the snow presence or absence for every pixel. These data were then used to compute the daily snow cover area in each watershed and the mean annual snow cover duration per pixel (SCD), i.e., the mean number of snow days per year. The dataset is available at https://doi.org/10.5281/zenodo.583733.

\section{Results and discussion}

In this section, we limited the data analysis to two snow seasons (2014-2016) because (1) the AWS network became fully operational with the installation of the third station in 2014 and (2) snow field observations were collected starting in snow season 2014-2015.

\subsection{Meteorology}

The observed average seasonal (average $30 \mathrm{~min}$ from 1 November to 30 June) surface air temperature for the two snow seasons (2014-2016) was 6.9, 4.3, and $-1.4^{\circ} \mathrm{C}$ for LAQ (monthly range: $\left.-0.3-17.1^{\circ} \mathrm{C}\right)$, MZA $\left(-2.9-14.3^{\circ} \mathrm{C}\right.$ ), and CED $\left(-7.1-8.4^{\circ} \mathrm{C}\right)$, respectively. There is a strong positive correlation in the $30 \mathrm{~min}$ surface air temperature records from the three stations $(r=92.7-97.9)$. Total annual precipitation ranged between 732 and $1125 \mathrm{~mm}$ during 20142015 and 1592 to $1880 \mathrm{~mm}$ for 2015-2016, representing precipitation data recorded at the LAQ and MZA stations, respectively (1840-2294 m a.s.1.). Average wind speeds for the same time period (2014-2016) were $2.4 \mathrm{~m} \mathrm{~s}^{-1}$ (monthly range: $1.5-3.3), 5.4$ (4.1-8.0), and $4.7 \mathrm{~m} \mathrm{~s}^{-1}$ (3.6-5.5) for LAQ, MZA, and CED, respectively. Strong winds seldom exceed $10 \mathrm{~m} \mathrm{~s}^{-1}$ at LAQ, $20 \mathrm{~m} \mathrm{~s}^{-1}$ at MZA, and $25 \mathrm{~m} \mathrm{~s}^{-1}$ at CED except during storm events, where maximum wind gusts recorded reached up to $40.1 \mathrm{~m} \mathrm{~s}^{-1}$ at CED. Seasonal incoming solar shortwave radiation averages (30 min averages) ranged between 156 and $219 \mathrm{~W} \mathrm{~m}^{-2}$ for the three stations (2014-2016).

\subsection{Snow depth, snow density, and SWE}

SWE peaks in mid-February at low and mid-altitude regions and in mid-March high mountainous regions. Snowmelt varies depending on elevation, beginning late February at lower altitudes and by mid-March at higher altitudes and extending into late April. Rain on snow events are common during winter season and usually occur at elevations below $1800 \mathrm{~m}$ a.s.l. Snow patches can persist until June in areas above $2700 \mathrm{~m}$ a.s.l. The median HS, SWE, and density obtained from snow courses (1300-2900 m a.s.l.) between 2014 and 2016 are shown in Fig. 6. The median HS, SWE, and density across different region and mountain elevation are illustrated in (Fig. 7). High regions like CED (1650-2900) and MZA (1300-2300) have higher mean HS and SWE when compared to mid- and low mountainous regions like LAQ (1300-1850). Median seasonal HS values at high elevations (i.e., mean for all CED and MZA snow courses; Fig. 7a, d) were very close, which reflects similar snowfall patterns. CED seasonal HS medians were 77 and $79 \mathrm{~cm}$, representing snow years 2014-2015 and 2015-2016, respectively, and similar values were found in MZA $(71$ and $76 \mathrm{~cm})$. Meanwhile, HS medians at LAQ were 53 and $54 \mathrm{~cm}$ over the same time period. The high mountainous regions above 2200 (e.g., CED) have a higher 75th quantile range and this is attributed to the extend snow persistence. The higher maximum HS observed in MZA can be attributed to the rough topography of the region, whereas the high region in CED above $2700 \mathrm{~m}$ a.s.l. is presented as a plateau with less variance in HS and SWE when compared to high regions in MZA (21002500).

Peak SWE values for the two winter seasons (20142015; 2015-2016) were 103 and $83 \mathrm{~cm}$ w.e. for CED, 127 and $158 \mathrm{~cm}$ w.e. for MZA, and 59 and $36 \mathrm{~cm}$ w.e. for LAQ. The peaks for SWE, and similarly for HS, observed at MZA (Fig. 7) are attributed to the topography of the region where wind-blown snow was more noticeable. Despite MZA being characterized by higher variability in the SWE and HS, observations at CED show higher seasonal medians for both variables, which is expected since CED is higher and the snow season extends longer than the one observed at MZA. SWE remains relatively constant during winter season and starts to melt starting mid-March or early April at regions above $2100 \mathrm{~m}$ a.s.l. Snowmelt at lower elevation (1600-2100 m a.s.l.) started earlier by mid-February and early March. Regions between 1300 and $2000 \mathrm{~m}$ a.s.l. are subject to rain on snow, which influences snowmelt processes during the entire snow season, especially in warm years. The higher variance and inter-seasonal variability in the observed SWE across the different regions (Fig. 5) illustrate the importance for monitoring snowpack dynamics in Mount Lebanon as it is the major contributor to the water resource system.

The median seasonal snow density for all snow courses over the 2-year period (2014-2016) (Fig. 6) was $476 \mathrm{~km} \mathrm{~m}^{-3}$ and ranged between 431 and $522 \mathrm{~kg} \mathrm{~m}^{-3}$, representing the 
(a)

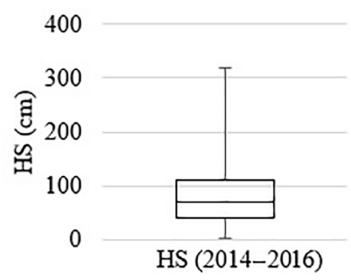

(b) 175

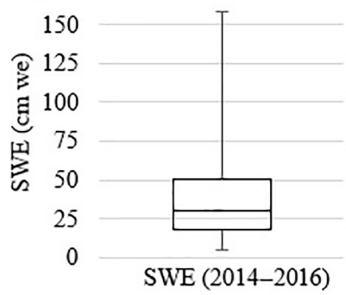

(c) 700

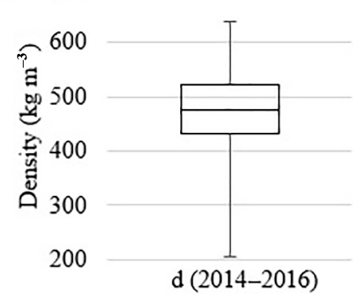

Figure 6. Box-and-whisker plots for nonzero data: (a) snow height (HS), (b) SWE, and (c) snow density over the two snow seasons of 2014-2016 using data from 30 snow courses located at elevations between 1300 and $2900 \mathrm{~m}$ a.s.1 $(n=649)$. The box brackets represent 25 and $75 \%$ of the data (lower and upper boxes, respectively). The whiskers are at minimum and maximum values.

(a) 350

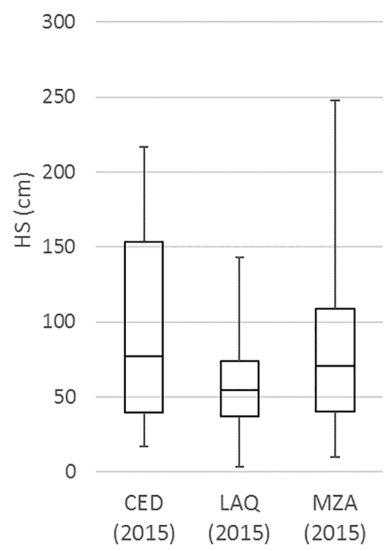

(d) 350

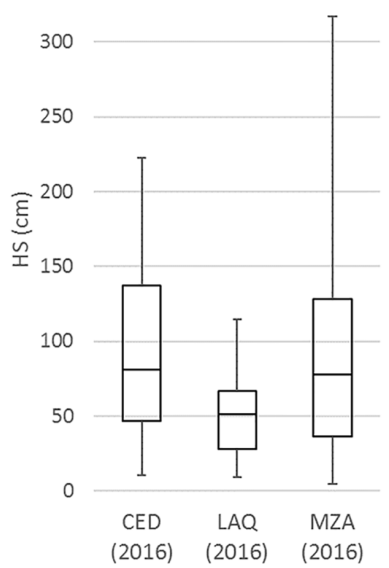

(b) 180

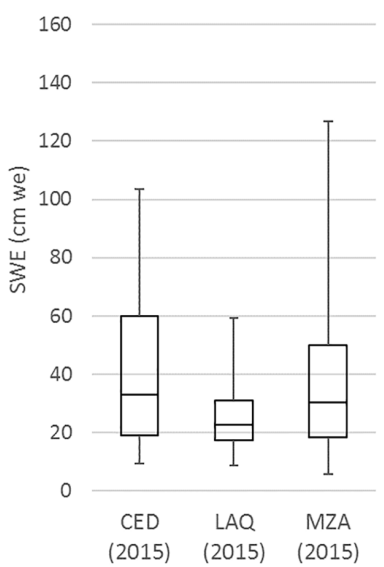

(e) 180

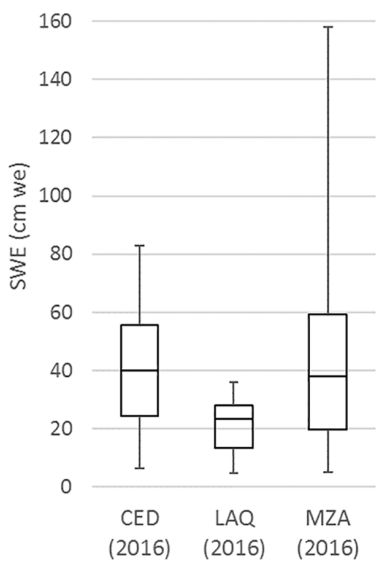

(c) 700

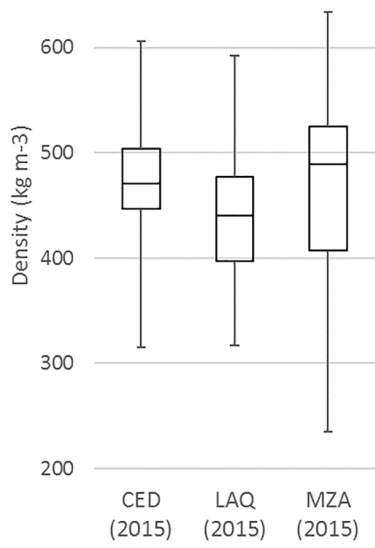

(f) 700

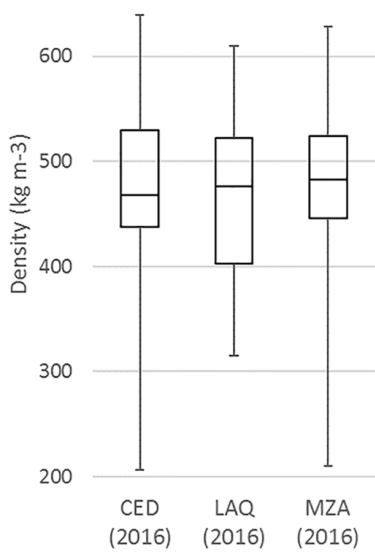

Figure 7. Box-and-whisker plots for nonzero data: (a) snow height (HS), (b) SWE, and (c) snow density over snow season 2014-2015 $(n=311)$ and (d) snow height (HS), (e) SWE, and (f) snow density over snow season 2015-2016 ( $n=371)$ distributed by region: CED (elevation range, 1650-2900 m), LAQ (1300-1850 m), and MZA (1350-2350 m). The box brackets represent 25 and $75 \%$ of the data (lower and upper boxes, respectively). The whiskers are at minimum and maximum values.

25th and 75th percentiles. Mean snow density for the three regions (Fig. 7c, f) over the two snow seasons (2014-2016) ranged between 440 and $489 \mathrm{~kg} \mathrm{~m}^{-3}$. These high seasonal density values are common in Mediterranean regions (e.g.,
Rice and Bales, 2010; López-Moreno et al., 2013). Although close median values can be observed for snow density across the different regions, it is worth noting that different snow metamorphism, compaction, or melting differences exist be- 

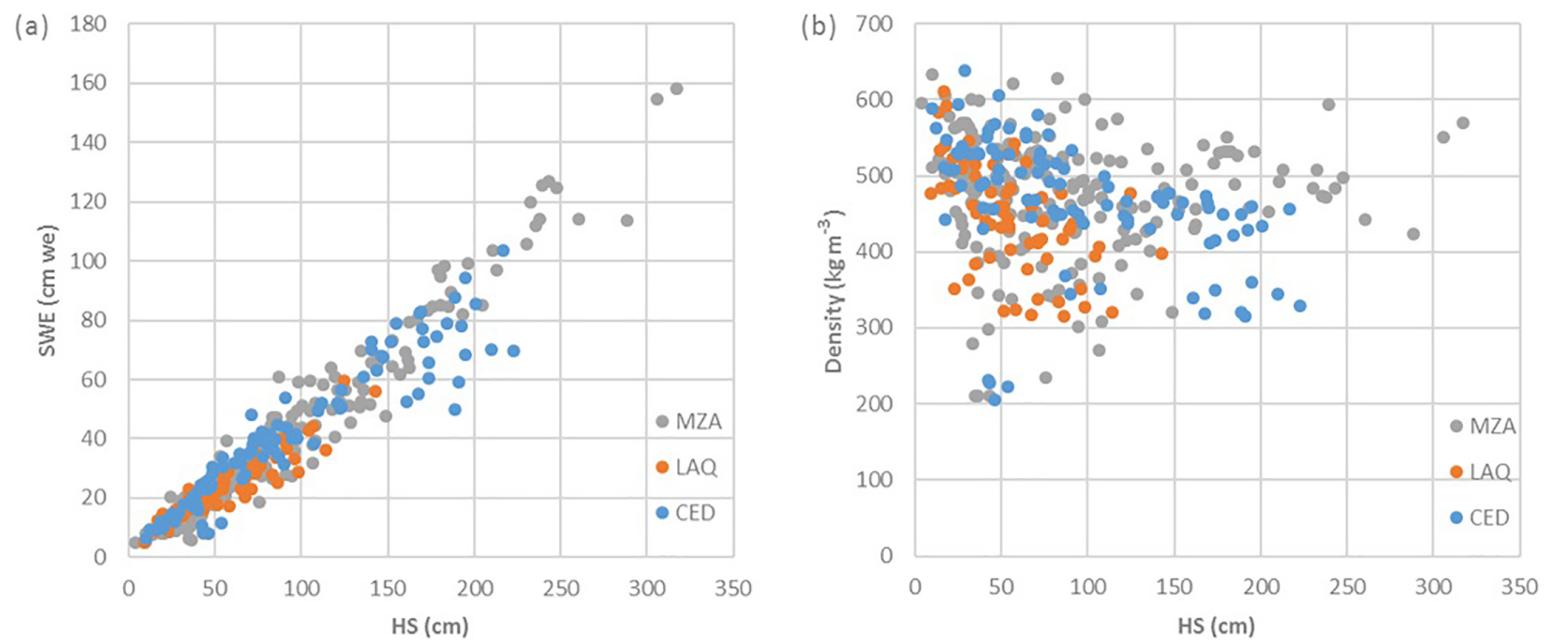

Figure 8. (a) SWE vs. height (HS) and (b) density vs. HS for all snow course data (observed during two snow seasons of 2014-2016 at elevations between 1300 and $2900 \mathrm{~m}$ a.s.1.) $(n=649)$.

tween regions. During the months of January and February the mid-altitude region (e.g., LAQ) snow is usually wetter and less compacted when compared to high-elevation regions (e.g., CED), where snow is usually wind-compacted, highly supportable, and dry.

Snow year 2015-2016 was characterized by rain-on-snow events, when most of the precipitation occurring a few days after the first major snowfall event (mid-January) fell as rain in mid-altitude regions (1300-2300 m a.s.1.). Rain on snow resulted in the disappearance of the snowpack below $1800 \mathrm{~m}$ a.s. 1 and accelerated the snow densification at elevations between 1800 and $2300 \mathrm{~m}$ a.s.l. Observed snow densities for the same date were 1.4-1.6 times higher than those observed during the same time period in the previous year (2014-2015).

\subsection{Modeling snow bulk density}

Establishing the relationship between distributed snow depth and SWE is among the used approaches to quantify SWE from snow depth measurements (e.g., Jonas et al., 2009). Figure 8 shows the general relationship between SWE vs. HS (Fig. 8a) and density vs. HS (Fig. 8b). The higher densities (Fig. 8b) are typical with Mediterranean, warm maritime, and alpine regions (e.g., Sturm et al., 2010). In contrast, the observed scatter between snow density and HS (Fig. 8b) cannot be explained using linear estimators. While SWE can be estimated linearly from HS, it is recommended to model the bulk density from HS and then derive SWE (Sturm et al., 2010). Such an approach is justified by the fact that (1) depth varies over a range that is many times greater than that of bulk density and (2) because estimates derived from measured depths and modeled densities are usually very close to measured values of SWE. The snow density can be estimated from HS using a linear function. However, a better represen-
Table 4. Model parameters by elevation bands for nonzero data.

\begin{tabular}{lrrrrr}
\hline $\begin{array}{l}\text { Elevation range } \\
\text { (ma.s.1.) }\end{array}$ & $\rho_{\max }$ & $\rho_{0}$ & $k_{1}$ & $k_{2}$ & $r^{2}$ \\
\hline $\begin{array}{l}2200-2900 \\
(n=136)\end{array}$ & 0.582 & 0.229 & 0.0004 & 0.0139 & 0.616 \\
$\begin{array}{l}1300-2900 \\
(n=353)\end{array}$ & 0.553 & 0.345 & 0.0000 & 0.0167 & 0.344 \\
\hline
\end{tabular}

tation of snow density from snow depth measurement can be achieved using a nonlinear function that include HS and accounts for the effect of snow aging (represented in terms of day of the year, DOY) (Sturm et al., 2010). Distinct classes for different climate regions are used to account, indirectly, for the effects of meteorological condition (i.e., temperature and wind) (Sturm et al., 2010). The general equation is a nonlinear function asymptotic to the maximum seasonal density (Sturm et al., 2010) (Eq. 6):

$\rho_{h_{i}}, \mathrm{DOY}_{i}=\left(\rho_{\max }-\rho_{0}\right)\left[1-e^{\left(-k_{1} \times h_{i}-k_{2} \times \mathrm{DOY}_{i}\right)}\right]+\rho_{0}$,

where $\rho_{\max }$ and $\rho_{0}$ are maximum and minimum bulk density, $k_{1}$ and $k_{2}$ are densification parameters, and $h_{i}$ is snow depth at the $i$ th observation. $\rho_{\max }, \rho_{0}, k_{1}$, and $k_{2}$ vary with climate region and the model parameters for the major snow class are found in Sturm et al. (2010) Table 4. The equation was applied to the ensemble points, presented in Fig. 8b, using snow depth and DOY as predictor variables and snow depth as predictand. The model parameters were $\rho_{\max }=0.553, \rho_{0}=$ $0.0345, k_{1}=0.0000$, and $k_{2}=0.0167$ for the entire dataset with the model explaining $34 \%$ (coefficient of determination $r^{2}=0.344$ ) of the snow density variability (Table 4 ). We believe that some of the observed differences between 

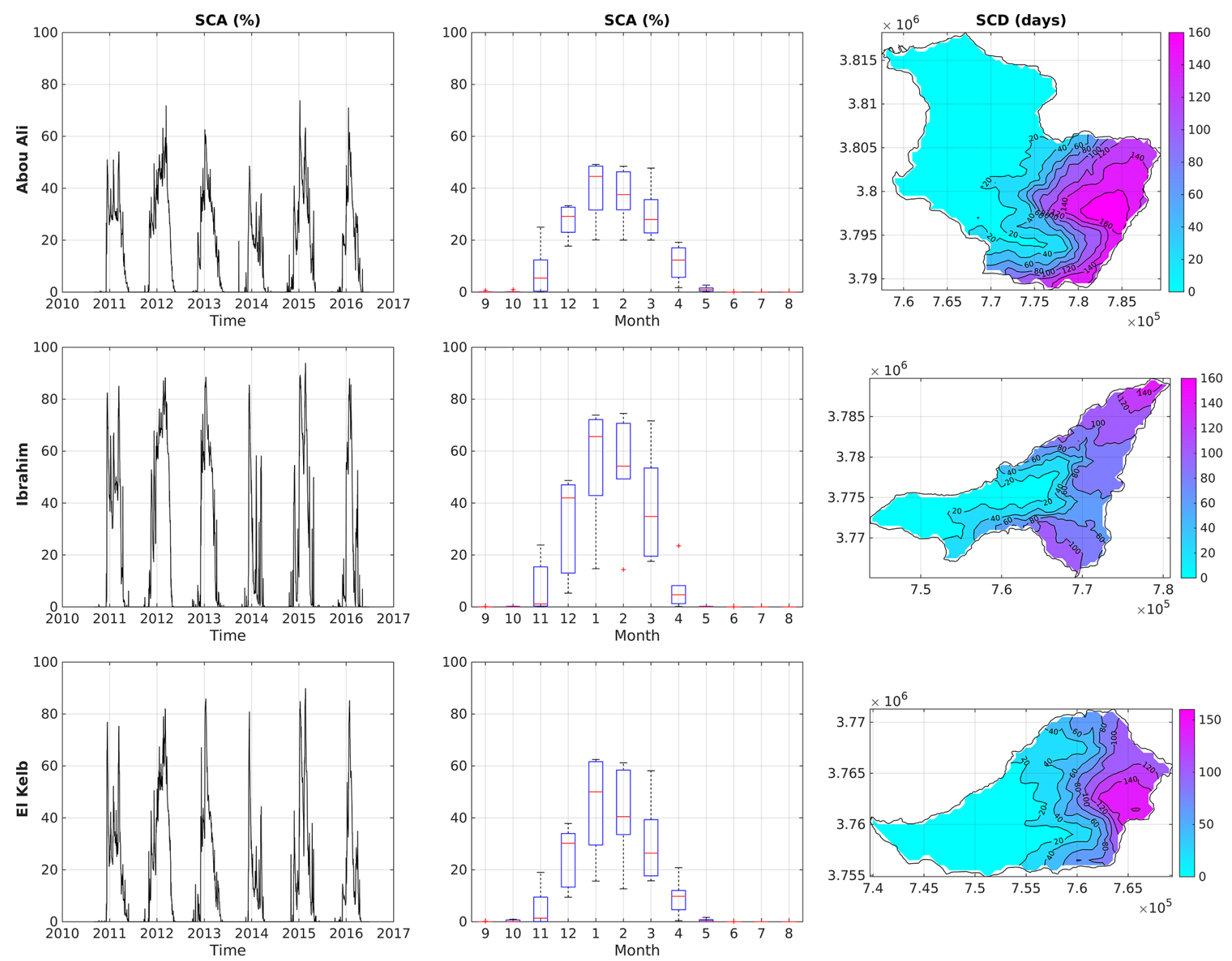

Figure 9. From left to right: time series of the snow cover area (SCA, percentage of the basin area), box plot of mean monthly SCA, and SCD for (from top to bottom) the Abou Ali, Ibrahim, and El Kelb River basins.

the current Mediterranean and the maritime and alpine regions in general can be attributed to the shorter snow season, warmer temperature, and higher densification rates, especially in the mid-elevation zone (1300-1900 m a.s.1.). During February field visits, most of the observed snow at this midelevation zone was wetter and characterized by higher densities when compared to high-elevation regions (e.g., above $2200 \mathrm{~m}$ a.s.l., where the snow was usually dry). A better snow density fit was achieved using elevation bands with a better fit for elevation above $2200 \mathrm{~m}$ (Table 4). The model was not able to explain the variability in snow densities to snow elevation in low mountain regions (1300-1800 m a.s.1.), namely because this region is subject to rain-on-snow events and multiple instances of snow accumulation and melt during a single snow season.

\subsection{Remote sensing snow cover data}

MODIS data indicate that snow storm events occurred between November and March. The snow cover area peaked between January and February. Maximum snow cover duration (SCD) was 160 days at higher altitudes (above $2700 \mathrm{~m}$ a.s.1.). SCD in medium-elevation mountain regions (2200-2600 m a.s.1.) ranged between 100 and 140 days per average year. The percent of snow-covered area (SCA) of the basins during winter months (December-March), for the years between 2011 and 2016, ranged between 28 and $46 \%$ (Abou Ali), 36 and $66 \%$ (Ibrahim), and 27 and 50\% (El Kelb) (Fig. 9).

\section{Data availability}

All data described in this paper are made publicly available at Zenodo (Fayad et al., 2017). Included are comma- 
separated files (.csv) for AWSs listing the three stations and snow course observation, as well as a compressed file for processed daily MODIS SCA and SCD.

\section{Conclusions}

This paper presents the first dataset of snow and meteorological conditions in Mount Lebanon. The observations focused on three major basins of the coastal region of Lebanon and cover the snow seasons between 2011 and 2016 (for MZA AWS located at $2300 \mathrm{~m}$ a.s.1.). The observation network became fully operational in 2014. The network includes three automatic stations covering the range of snow-dominated areas between 1840 and $2834 \mathrm{~m}$ a.s.l. Distributed in situ HS and SWE measurements were also collected during two snow seasons (2014-2016) at 30 different snow courses located between 1300 and $2900 \mathrm{~m}$ a.s.l. MODIS snow products were processed to compute SCA and SCD at the basin scale. These observations are the result of an ongoing joint collaboration between IRD (France), CESBIO (France), CNRS/NCRS (Lebanon), and USJ (Lebanon). The observatory is currently being funded for 2 years (2016-2018) via grants from CNRS/NCRS, IRD, and USJ.

Additional unpublished data observations may also be available to complete this dataset, including meteorological data collected by the meteorological services at the department of civil aviation and the Lebanese Agricultural Research Institute (LARI), and river and spring discharges monitored by the Litani River Authority (LRA) as well as meteorological and hydrological data combined by the early warning system at the National Center For Remote Sensing (NCRS) and the observational datasets at the Centre d'Information et de Formation aux Métiers de l'Eau (CIFME) at the Ministry of Energy and Water (MOEW).

We provided mean and seasonal snow properties over two snow seasons (2014-2016) and provided an example on how SWE and snow density can be obtained using only HS measurements. This time span is insufficient to characterize the temporal variability in the snow cover. However, it already provides consistent information on the snow spatial variability. The combination of the meteorological station, snow courses, and remote sensing data through the application of a snowpack model will enable a multi-year evaluation of the snow resources at the basin scales.

The accurate representation of the spatial distribution of HS, SWE, and snow density is crucial for hydrological applications. In particular, we are using the AWS data for running a distributed energy balance model. The snow observations also hold potential for the characterization of the spatial distribution of snow across different gradients. SCA and SCD data can be used for model validation or as an operational tool for water resource management (e.g., Sproles et al., 2016). The AWS data may also support the validation and downscaling of regional climate models for various ap- plications beyond the study of snow hydrology and the use of water resources.

Competing interests. The authors declare that they have no conflict of interest.

Special issue statement. This article is part of the special issue "Hydrometeorological data from mountain and alpine research catchments". It is not associated with a conference.

Acknowledgements. This publication was made possible through support provided by the French National Research Institute for Sustainable Development (IRD) and the Lebanese National Council for Scientific Research (CNRS). We thank the editor and the two anonymous reviewers for their insightful comments that have improved the presentation of this paper.

Edited by: Danny Marks

Reviewed by: two anonymous referees

\section{References}

Aouad-Rizk, A., Job, J.-O., Khalil, S., Touma, T., Bitar, C., Boqcuillon, C., and Najem, W.: Snow in Lebanon: a preliminary study of snow cover over Mount Lebanon and a simple snowmelt model/Etude préliminaire du couvert neigeux et modèle de fonte des neige pour le Mont Liban, Hydrolog. Sci. J., 50, 555-569, https://doi.org/10.1623/hysj.50.3.555.65023, 2005.

Bakalowicz, M., Hakim, M., and El-Hajj, A.: Karst groundwater resources in the countries of eastern Mediterranean: the example of Lebanon, Environmental Geology, 54, 597-604, https://doi.org/10.1007/s00254-007-0854-z, 2008.

Bernier, M., Fortin, J. P., Gauthier, Y., Corbane, C., Somma, J., and Dedieu, J. P.: Intégration de données satellitaires à la modélisation hydrologique du Mont Liban, Hydrolog. Sci. J., 48, 9991012, https://doi.org/10.1623/hysj.48.6.999.51428, 2003.

Brutsaert, W.: Evaporation into the atmosphere: theory, history and applications (Vol. 1), Springer Science \& Business Media, https://doi.org/10.1007/978-94-017-1497-6, 2013.

Buisán, S. T., Earle, M. E., Collado, J. L., Kochendorfer, J., Alastrué, J., Wolff, M., Smith, C. D., and López-Moreno, J. I.: Assessment of snowfall accumulation underestimation by tipping bucket gauges in the Spanish operational network, Atmos. Meas. Tech., 10, 1079-1091, https://doi.org/10.5194/amt10-1079-2017, 2017.

Corbane, C., Somma, J., Bernier, M., Fortin, J. P., Gauthier, Y., and Dedieu, J. P.: Estimation de L'équivalent en Eau du Couvert Nival en Montagne Libanaise à Partir des Images RADARSAT1/Estimation of Water Equivalent of the Snow Cover in Lebanese Mountains by Means of RADARSAT-1 Images, Hydrolog. Sci. J., 50, 355-370, https://doi.org/10.1623/hysj.50.2.355.61802, 2005.

Devine, K. A. and Mekis, É.: Field accuracy of Canadian rain measurements, Atmos. Ocean., 46, 213-227, https://doi.org/10.3137/ao.460202, 2008. 
Dixon, D. and Boon, S.: Comparison of the SnowHydro snow sampler with existing snow tube designs, Hydrol. Process., 26, 25552562, https://doi.org/10.1002/hyp.9317, 2012.

Doummar, J., Geyer, T., Baierl, M., Nödler, K., Licha, T., and Sauter, M.: Carbamazepine breakthrough as indicator for specific vulnerability of karst springs: Application on the Jeita spring, Lebanon, Appl. Geochem., 47, 150-156, https://doi.org/10.1016/j.apgeochem.2014.06.004, 2014.

Estévez, J., Gavilán, P., and Giráldez, J. V.: Guidelines on validation procedures for meteorological data from automatic weather stations, J. Hydrol., 402, 144-154, https://doi.org/10.1016/j.jhydrol.2011.02.031, 2011.

Fayad, A., Gascoin, S., Faour, G., Fanise, P., and Drapeau, L.: Snow dataset for Mount-Lebanon (2011-2016), https://doi.org/10.5281/zenodo.583733, 2017.

Gascoin, S., Hagolle, O., Huc, M., Jarlan, L., Dejoux, J.-F., Szczypta, C., Marti, R., and Sánchez, R.: A snow cover climatology for the Pyrenees from MODIS snow products, Hydrol. Earth Syst. Sci., 19, 2337-2351, https://doi.org/10.5194/hess-19-23372015, 2015.

Hall, D. K., Riggs, G. A., and Salomonson, V. V.: MODIS/Terra Snow Cover 5-Min L2 Swath $500 \mathrm{~m}$. Version 5, NASA National Snow and Ice Data Center Distributed Active Archive Center, Boulder, Colorado USA, https://doi.org/10.5067/ACYTYZB9BEOS, 2006.

Harder, P. and Pomeroy, J.: Estimating precipitation phase using a phycrometric energy balance method, Hydrol. Process., 27, 1901-1914, https://doi.org/10.1002/hyp.9799, 2013.

Harpold, A. A., Kaplan, M. L., Klos, P. Z., Link, T., McNamara, J. P., Rajagopal, S., Schumer, R., and Steele, C. M.: Rain or snow: hydrologic processes, observations, prediction, and research needs, Hydrol. Earth Syst. Sci., 21, 1-22, https://doi.org/10.5194/hess-21-1-2017, 2017.

Herrero, J. and Polo, M. J.: Evaposublimation from the snow in the Mediterranean mountains of Sierra Nevada (Spain), The Cryosphere, 10, 2981-2998, https://doi.org/10.5194/tc-10-29812016, 2016.

Hreiche, A., Najem, W., and Bocquillon, C.: Hydrological impact simulations of climate change on Lebanese coastal rivers /Simulations des impacts hydrologiques du changement climatique sur les fleuves côtiers Libanais, Hydrolog. Sci. J., 52, 1119-1133, https://doi.org/10.1623/hysj.52.6.1119, 2007.

Huwald, H., Higgins, C. W., Boldi, M.-O., Bou-Zeid, E., Lehning, M., and Parlange, M. B.: Albedo effect on radiative errors in air temperature measurements, Water Resour. Res., 45, W08431, https://doi.org/10.1029/2008WR007600, 2009.

Jonas, T., Marty, C., and Magnusson, J.: Estimating the snow water equivalent from snow depth measurements in the Swiss Alps, J. Hydrol., 378, 161-167, https://doi.org/10.1016/j.jhydrol.2009.09.021, 2009.

Kalaoun, O., Al Bitar, A., Gastellu-Etchegorry, J.-P., and Jazar M.: Impact of Demographic Growth on Seawater Intrusion: Case of the Tripoli Aquifer, Lebanon, Multidisciplinary Digital Publishing Institute, Water, 8, 104, https://doi.org/10.3390/w8030104, 2016.

Königer, P. and Margane, A.: Stable Isotope Investigations in the Jeita Spring catchment, Technical Cooperation Project Protection of Jeita Spring, BGR Technical Report No. 12., 56 pp., Hannover, Germany, 2014.
López-Moreno, J. I., Fassnacht, S. R., Heath, J. T., Musselman, K. N., Revuelto, J., Latron, J., Morán-Tejeda, E., and Jonas, T.: Small scale spatial variability of snow density and depth over complex alpine terrain: Implications for estimating snow water equivalent, Adv. Water Resour., 55, 4052, https://doi.org/10.1016/j.advwatres.2012.08.010, 2013.

Malek, E: The daily and annual effects of dew, frost, and snow on a non-ventilated net radiometer, Atmos. Res., 89, 243-251, https://doi.org/10.1016/j.atmosres.2008.02.006, 2008.

Margane, A., Schuler, P., Königer, P., Abi Rizk, J., Stoeckl, L., and Raad, R.: Hydrogeology of the Groundwater Contribution Zone of Jeita Spring. Technical Cooperation Project Protection of Jeita Spring, BGR Technical Report No. 5, 317 pp., Raifoun, Lebanon, 2013.

Marks, D., Winstral, A., Reba, M., Pomeroy, J., and Kumar, M.: An evaluation of methods for determining during-storm precipitation phase and the rain/snow transition elevation at the surface in a mountain basin, Adv. Water Resour., 55, 98-110, 2013.

Mhawej, M., Faour, G., Fayad, A., and Shaban, A.: Towards an enhanced method to map snow cover areas and derive snow-water equivalent in Lebanon, J. Hydrol., 513, 274-282, https://doi.org/10.1016/j.jhydrol.2014.03.058, 2014.

Ministry of Energy and Water (MOEW): National Water Sector Strategy (NWSS) Report, Beirut, Lebanon, 2010.

National Council for Scientific Research (NCRS): Land-use land cover map of Lebanon, Beirut, Lebanon, available at: http:// www.cnrs.edu.lb/ (last access: 9 January 2017), 2015.

Pan, X., Yang, D., Li, Y., Barr, A., Helgason, W., Hayashi, M., Marsh, P., Pomeroy, J., and Janowicz, R. J.: Bias corrections of precipitation measurements across experimental sites in different ecoclimatic regions of western Canada, The Cryosphere, 10, 2347-2360, https://doi.org/10.5194/tc-10-2347-2016, 2016.

Rasmussen, R., Dixon, M., Hage, F., Cole, J., Wade, C., Tuttle, L., McGettigan, S., Carty, T., Stevenson, L., Fellner, W., Knight, S., Karplus, E., and Rehak, N.: Weather support to deicing decision making (WSDDM): A winter weather nowcasting system, B. Am. Meteorol. Soc., 82, 579-595, 2001.

Rasmussen, R., Baker, B., Kochendorfer, J., Meyers, T., Landolt, S., Fischer, A., Black, J., Thériault, J., Kucera, P., Gochis, D., Smith, C., Nitu, R., Hall, M., Ikeda, K., and Gutmann, E.: How Well Are We Measuring Snow: The NOAA/FAA/NCAR Winter Precipitation Test Bed, B. Am. Meteorol. Soc., 93, 811-829, https://doi.org/10.1175/BAMS-D-11-00052.1, 2012.

Rice, R. and Bales, R.: Embedded-sensor network design for snow cover measurements around snow pillow and snow course sites in the Sierra Nevada of California, Water Resour. Res., 46, W03537, https://doi.org/10.1029/2008wr007318, 2010.

Serreze, M., Clark, M., Armstrong, R., McGinnis, D., and Pulwarty, R.: Characteristics of the western United States snowpack from snowpack telemetry (SNOTEL) data, Water Resour. Res., 35, 2145-2160, https://doi.org/10.1029/1999wr900090, 1999.

Shaban, A., Faour, G., Khawlie, M., and Abdallah, C.: Remote sensing application to estimate the volume of water in the form of snow on Mount Lebanon/Application de la télédétection à l'estimation du volume d'eau sous forme de neige sur le Mont Liban, Hydrolog. Sci. J., 49, 643-653, https://doi.org/10.1623/hysj.49.4.643.54432, 2004.

Shafer, M., Fiebrich, C., Arndt, D., Fredrickson, S., and Hughes, T.: Quality Assurance Procedures in 
the Oklahoma Mesonetwork, J. Atmos. Ocean. Tech., 17, 474-494, https://doi.org/10.1175/15200426(2000)017<0474:QAPITO>2.0.CO;2, 2000.

Smith, C. D., Kontu, A., Laffin, R., and Pomeroy, J. W.: An assessment of two automated snow water equivalent instruments during the WMO Solid Precipitation Intercomparison Experiment, The Cryosphere, 11, 101-116, https://doi.org/10.5194/tc11-101-2017, 2017.

Somma, J., Luxey, P., and Dhont, D.: Snow Volumes 3D Modeling on the Karstic Plateau of Mount Lebanon (Lebanon), AGU, Fall Meeting 2006, 11-15 December 2006, San Francisco, CA, USA , abstract \# H11B-1260, 2006.

Somma, J., Drapeau, L., Abou Chakra, C., and El-Ali, T.: Geomatics contributions to key indicators for estimation and monitoring of snow cover input to hydrogeological resources, AGU, Fall Meeting 2014, 15-19 December 2014, San Francisco, CA, USA, abstract \# C43C-0404, 2014.

Sproles, E. A., Kerr, T., Orrego Nelson, C., and Lopez Aspe, D.: Developing a Snowmelt Forecast Model in the Absence of Field Data, Water Resour. Manage., 30, 2581-2590, https://doi.org/10.1007/s11269-016-1271-4, 2016

Sturm, M., Taras, B., Liston, G., Derksen, C., Jonas, T., and Lea, J.: Estimating Snow Water Equivalent Using Snow Depth Data and Climate Classes, J. Hydrometeorol., 11, 1380-1394, 2010.
Telesca, L., Shaban, A., Gascoin, S., Darwich, T., Drapeau, L., Hage, M., and Faour, G.: Characterization of the time dynamics of monthly satellite snow cover data on Mountain Chains in Lebanon, J. Hydrol., 519, 3214-3222, https://doi.org/10.1016/j.jhydrol.2014.10.037, 2014.

Thériault, J. M., Rasmussen, R., Ikeda, K., and Landolt, S.: Dependence of Snow Gauge Collection Efficiency on Snowflake Characteristics, J. Appl. Meteorol. Clim., 51, 745-762, 2012.

UN Development Programme (UNDP): Assessment of Groundwater Resources of Lebanon, Beirut, available at: http://www.lb. undp.org/content/lebanon/en/home/library/environment_energy/ assessment-of-groundwater-resources-of-lebanon.html (last access: 7 August 2017), 2014

World Meteorological Organization (WMO): Guide to Meteorological Instruments and Methods of Observations, WMO-No. 8, Geneva, Switzerland, 2008.

Yang, D., Goodison, B. E., Benson, C. S., and Ishda, S.: Adjustment of daily precipitation at 10 climate stations in Alaska: Application of the World Meteorological Organization intercomparison results, Water Resour. Res., 34, 241-256, 1998. 